\title{
ASSESSMENT OF THE EFFECT OF SELECTED COMPONENTS OF EQUINE SEMINAL PLASMA ON SEMEN FREEZABILITY
}

\author{
Miroslava Mráčková, Marta Zavadilová, Markéta Sedlinská \\ Department of Reproduction, Equine Clinic, Faculty of Veterinary Medicine, \\ University of Veterinary and Pharmaceutical Sciences Brno, Brno, Czech Republic
}

Received 29 September 2014; Received in revised form 2 January 2015; Accepted 16 January 2015

\begin{abstract}
In this study, selected components of seminal plasma in equine semen were evaluated. Levels of enzymes, electrolytes, microelements and some other components were observed. The aim of this study was to find some important differences between the levels of these components and the total sperm motility after freezing and thawing (freezability of the semen). Total of 32 ejaculates from 7 stallions were collected, assessed and prepared in $0,5 \mathrm{ml}$ straws for freezing. After thawing, the sperm motility was analyzed and ejaculates were divided into two groups: "good" freezable and "poor" freezable. The only statistically significant difference between groups of ,good" and ,poor" freezable ejaculates was in the concentration of vitamin E in the seminal plasma. In the group of „good“ freezable ejaculates, the level of vitamin E was significantly lower $(p \leq 0,05)$ than in the group of "poor" freezable ejaculates.
\end{abstract}

Key words: stallion, seminal plasma, semen freezing, vitamin E

\section{INTRODUCTION}

Seminal plasma is a very important part of the ejaculate and it is involved in many sperm functions, especially in the metabolism and in events preceding fertilization. But nevertheless, the physiological role of seminal plasma and its components is still not fully understood (1). Also, the effect of seminal plasma on sperm during storage, freezing or cooling is not completely clear.

So far, not many studies about the components of seminal plasma and the freezability of the ejaculate have been conducted. Until now, studies in horses have not shown that it is possible to predict the freezability of semen based on the concentration of some enzymes, microelements (2), total protein or composition of the protein spectrum (3).

Corresponding author: Dr. Miroslava Mráčková, $\mathrm{PhD}$ E-mail address: mrackovam@vfu.cz

Present address: Equine Clinic, University of Veterinary and Pharmaceutical Sciences Brno, Palackého tr. 1/3, 61242 Brno, Czech Republic

Phone: + 420731476742

Copyright: (C) 2015 Mráčková M. This is an open-access article published under the terms of the Creative Commons Attribution License which permits unrestricted use, distribution, and reproduction in any medium, provided the original author and source are credited. Competing Interests: The authors have declared that no competing interests exist.

Available Online First: 19 January 2015

http://dx.doi.org/10.14432/j.macvetrev.2015.01.037
However, questionable or different information is found in certain studies or in studies on other animal species (4).

\section{MATERIAL AND METHODS}

\section{Animals and semen collection}

In this experiment, 7 licensed stallions were used. The stallions represented various breeds and ranged in age from 4 to 16 years old. During the semen collection, animals were stabled and fed at the Equine Clinic, University of Veterinary and Pharmaceutical Sciences Brno. All of them were in good clinical status and used in breeding with normal fertility. From each stallion 1 to 11 ejaculates were collected, but only 32 ejaculates were used in this study. Four ejaculates were excluded because they did not meet some of the basic quality requirements for semen freezing (2x low percentage of motile sperm, $2 \mathrm{x}$ urospermia).

The ejaculates were collected routinely using the Missouri model artificial vagina while stallions were mounted on a dummy with teasing mare standing in front of the phantom.

\section{Evaluation of collected semen}

Following collection, each ejaculate was filtered with non-woven semen filter (Minitüb, 
Germany) to remove the gel fraction. Overall 36 ejaculates were collected and evaluated. After filtration a macroscopic examination was done: volume, color, odor and viscosity were evaluated. In the microscopic evaluation total sperm motility, concentration and morphology were included. Total sperm motility was assessed by light microscope with phase contrast (enlargement 400x) by one person to eliminate the influence of different observers. Concentration was counted in a Burker chamber and morphology was examined at high power under immersion oil (enlargement 1000x) using Giemsa stain.

\section{Semen processing and freezing}

After the macroscopic evaluation of each ejaculate, samples for microscopic evaluation were taken and the ejaculate was centrifuged ( $1000 \mathrm{G}$ for 10 minutes). Seminal plasma was collected using a sterile syringe and the sediment of the sperm was diluted with French diluent in the concentration of $800 \times 10^{6}$ sperm per $\mathrm{ml}$. The diluted semen was transferred to $0,5 \mathrm{ml}$ straws and after 2 hours of equilibration in a fridge $\left(+4^{\circ} \mathrm{C}\right)$, it was frozen in liquid nitrogen.

Samples with seminal plasma were kept frozen in a freezer $\left(-18^{\circ} \mathrm{C}\right)$ until analysis. After the gathering of all samples, the samples were thawed and examined in the Large Animal Clinical Laboratory at UVPS Brno.

For biochemical analysis, the spectrophotometry analyzer LIASYS (Analyzer Medical System, Italy) was used.

The concentration of microelements was measured by using flame atomic absorption spectrometry 3500 Atomic Absorption Spectrometer (Thermo Electron Corporation).

\section{Evaluation of thawed semen}

Frozen-thawed ejaculate was evaluated at least 24 hours after freezing. The straws were thawed in a water bath at $38,5^{\circ} \mathrm{C}$ for 30 seconds. Total sperm motility was assessed in a light microscope with phase contrast (enlargement 400x) immediately after thawing, in every case by one person. The total sperm motility after thawing was always the criterion for the evaluation of freezability. Ejaculates were divided into two groups (A, B):

Group A:

Ejaculates with post-thaw sperm motility $\geq 35 \%$ were classified as ,good“ freezeble $(\mathrm{n}=18)$.

Group B:

Ejaculates with post-thaw sperm motility $<35 \%$ were classified as"poor" freezable $(\mathrm{n}=14)$.

\section{Statistical evaluation}

Results from group A and B were compared by a nonparametric Wilcoxon signed rank test for unpaired data. In cases where the result from the laboratory was disproportionately high or low, this result was not used in this study. If these extreme results were used, the overall result could be influenced and distorted by them.

\section{RESULTS}

Average values of basic parameters of ejaculates in both groups are shown in Table 1. The results of the measured selected parameters, which were monitored in the seminal plasma, are arranged in Table 2. Two parameters which were monitored, but not shown in the table, are cholesterol and vitamin A. In all samples the level of these parameters was zero.

Table 1. Average values of basic parameters of ejaculates in groups A and B (Motility II: motility after thawing)

\begin{tabular}{lcc}
\hline & $\begin{array}{c}\text { Group A } \\
\text { (ejaculates with post-thaw } \\
\text { motility } \geq 35 \%)\end{array}$ & $\begin{array}{c}\text { Group B } \\
\text { (ejaculates with post-thaw } \\
\text { motility }<35 \%)\end{array}$ \\
\hline Volume (without gel fraction) (ml) & Mean \pm SD & Mean \pm SD \\
Motility after collection (\%) & $68,9 \pm 28,36$ & $65,9 \pm 46,06$ \\
Sperm concentration $\left(\times 10^{6} / \mathrm{mm}^{3}\right)$ & $73,4 \pm 5,77$ & $61,4 \pm 9,90$ \\
Morphologically abnormal sperm (\%) & $123,6 \pm 80,54$ & $129,1 \pm 108,74$ \\
Motility II (\%) & $28,0 \pm 5,88$ & $33,1 \pm 13,52$ \\
Sperm concentration after thawing $\left(\times 10^{6} / \mathrm{mm}^{3}\right)$ & $41,7 \pm 7,07$ & $19,1 \pm 12,92$ \\
Morphologically abnormal sperm after thawing $(\%)$ & $889,6 \pm 319,90$ & $730,1 \pm 361,76$ \\
\hline
\end{tabular}


Effect of selected components of equine seminal plasma on semen freezability

After the statistical analysis of both groups of ejaculates, the only significant difference $(p \leq 0,05)$ was in the concentration of vitamin $\mathrm{E}$ in the seminal plasma. In the group of ejaculates where motility after thawing was $\geq 35 \%$, concentration of vitamin E was significantly lower $(p \leq 0,05)$ than in the group of ejaculates with motility $<35 \%$ after thawing.
In this study we tried to find differences in the composition of seminal plasma between ,good“ and „poor“ freezable ejaculates in stallions. The only monitored parameter: vitamin E showed statistically significant differences $(p \leq 0,05)$ between the two groups listed above. It is interesting that higher levels of vitamin E were found in the group of ,,poor"

Table 2. Average values of selected biochemical parameters of ejaculates in groups A and B

\begin{tabular}{|c|c|c|c|c|}
\hline \multirow[b]{2}{*}{ Monitored parameter } & \multicolumn{2}{|c|}{$\begin{array}{c}\text { Group A } \\
\text { (ejaculates with post-thaw } \\
\text { motility } \geq 35 \% \text { ) }\end{array}$} & \multicolumn{2}{|c|}{$\begin{array}{c}\text { Group B } \\
\text { (ejaculates with post-thaw } \\
\text { motility }<35 \% \text { ) }\end{array}$} \\
\hline & $\mathbf{n}$ & Mean \pm SD & $\mathbf{n}$ & $\operatorname{Mean} \pm \mathrm{SD}$ \\
\hline Total protein $(\mathrm{g} / \mathrm{l})$ & 18 & $5,9 \pm 2,99$ & 14 & $7,7 \pm 4,67$ \\
\hline Creatinine $(\mu \mathrm{mol} / \mathrm{l})$ & 18 & $54,3 \pm 19,42$ & 13 & $53,2 \pm 21,23$ \\
\hline Urea $(\mathrm{mmol} / \mathrm{l})$ & 18 & $6,7 \pm 0,91$ & 14 & $6,2 \pm 1,26$ \\
\hline Alkaline phosphatase (ALP) $(\mu \mathrm{kat} / \mathrm{l})$ & 13 & $65,9 \pm 28,96$ & 8 & $56,4 \pm 38,29$ \\
\hline Alanine amino-transferase (ALT) $(\mu \mathrm{kat} / \mathrm{l})$ & 18 & $0,2 \pm 0,06$ & 14 & $0,2 \pm 0,08$ \\
\hline Aspartate-amino-transferase (AST) $(\mu \mathrm{kat} / \mathrm{l})$ & 18 & $0,9 \pm 0,81$ & 14 & $0,9 \pm 0,51$ \\
\hline Creatinekinase (CK) $(\mu \mathrm{kat} / \mathrm{l})$ & 13 & $2,1 \pm 1,56$ & 13 & $2,2 \pm 1,13$ \\
\hline Gama-glutamyl-transferase (GMT) $(\mu \mathrm{kat} / \mathrm{l})$ & 11 & $54,6 \pm 14,61$ & 6 & $47,7 \pm 18,74$ \\
\hline Lactate-dehydrogenase (LDH) ( $\mu \mathrm{kat} / \mathrm{l})$ & 10 & $0,5 \pm 0,31$ & 9 & $0,6 \pm 0,25$ \\
\hline $\mathbf{N a}^{+}(\mathrm{mmol} / \mathrm{l})$ & 18 & $109,6 \pm 17,97$ & 14 & $109,1 \pm 20,49$ \\
\hline $\mathbf{K}^{+}(\mathrm{mmol} / \mathrm{l})$ & 18 & $21,9 \pm 5,77$ & 14 & $24,5 \pm 10,55$ \\
\hline $\mathrm{Ca}(\mathrm{mmol} / \mathrm{l})$ & 17 & $2,3 \pm 0,80$ & 12 & $1,7 \pm 1,23$ \\
\hline $\mathbf{P}(\mathrm{mmol} / \mathrm{l})$ & 18 & $0,7 \pm 0,44$ & 13 & $0,8 \pm 0,45$ \\
\hline $\mathbf{C l}(\mathrm{mmol} / \mathrm{l})$ & 18 & $124,7 \pm 17,15$ & 14 & $117,2 \pm 17,00$ \\
\hline $\mathbf{Z n S}(\mu \mathrm{g} / \mathrm{l})$ & 18 & $4,8 \pm 2,02$ & 12 & $4,9 \pm 2,29$ \\
\hline $\mathbf{C u}(\mu \mathrm{g} / 1)$ & 17 & $4,1 \pm 2,17$ & 12 & $5,2 \pm 3,11$ \\
\hline $\operatorname{Mg}(\mu \mathrm{g} / 1)$ & 18 & $1,8 \pm 0,94$ & 14 & $1,3 \pm 0,63$ \\
\hline $\operatorname{Se}(\mu \mathrm{g} / \mathrm{l})$ & 17 & $5,7 \pm 3,69$ & 13 & $6,5 \pm 3,43$ \\
\hline Vitamin $\mathbf{E}(\mathrm{mmol} / \mathrm{l})$ & 18 & $0,015 \pm 0,0269^{*}$ & 14 & $0,068 \pm 0,0720^{*}$ \\
\hline
\end{tabular}

${ }^{*} \mathrm{p} \leq 0,05$

\section{DISCUSSION}

The results of some studies show that seminal plasma negatively affects sperm during short term and also long term storage (5-7). Some other studies denote that in humans (8), and also in stallions (9-11) the presence or adding specific amounts of seminal plasma before storage seems to improve sperm motility during cooled storage and also after thawing. However, the effect of seminal plasma differs significantly between individual stallions $(12,13)$. freezable ejaculates (mean $68 \mu \mathrm{mol} / \mathrm{l}$ ), while in the group of ,good" freezable ejaculates the mean value of vitamin E was only $15 \mu \mathrm{mol} / \mathrm{l}$. During semen cryopreservation in humans, the adding of vitamin E to extender in a dose $200 \mu \mathrm{mol}$ has positive effects on sperm motility in samples from fertile and also subfertile men. When vitamin $\mathrm{E}$ in a dose $100 \mu \mathrm{mol}$ was added, no positive effect on sperm motility was observed (14). Similar observations were made in boars (15), but adding vitamin E to the extender had no effect on sperm motility. When levels of vitamin E were measured in the fresh ejaculate of men (16), 
no correlation between vitamin $\mathrm{E}$ ( $\alpha$-tocopherol) and sperm motility was found. It is a question if the difference between concentrations of vitamin $\mathrm{E}$ in our two groups of ejaculates is not just an accidental finding because of the very low concentration of this vitamin in stallion seminal plasma or if sperm motility after freezing and thawing is really influenced by vitamin $\mathrm{E}$. This vitamin is well known as an antioxidant. It is possible that lower use of vitamin $\mathrm{E}$ in the antioxidant processes in ,poor“ freezable ejaculates is the reason for its higher level in this group of ejaculates. However, more samples and further studies are necessary for confirmation or refutation of the results of our study.

The antioxidant role of vitamin $\mathrm{E}$ and selenium is very closely related. In the study of Mahmoud et al. (17) it was demonstrated that supplementation of selenium and vitamin $\mathrm{E}$ in parenteral form in rams has a positive effect on the quality and quantity of semen. Similar observations were made in stallions (18). The authors proved that oral supplementation with selenium, vitamin $\mathrm{E}$ and zinc in stallions leads to the improvement of some quality parameters in ejaculate, especially the improvement of sperm motility. However, the results of another study did not show any improvement of sperm motility in fresh ejaculate and in ejaculate after 24 hours of storage at $5^{\circ} \mathrm{C}$ when stallions and pony stallions were supplemented with a combination of vitamin E, vitamin C, L-carnitine and folic acid (19). Over the last few years there has been a lot of work on antioxidants, fat acid or commercially available feed additive dietary supplementation, but the results are not very conclusive (20-22). Unfortunately, in none of the studies the levels of supplemented substances were not monitored in seminal plasma.

In this study not only vitamin $\mathrm{E}$ was determined, but also selenium. No statistically significant difference was found in the concentration of selenium. From the observations of Bertelsmann et al. (23) it is obvious that in stallions the level of selenium in the blood does not corresponded with the level of selenium in seminal plasma, but the concentration of selenium positively correlated with sperm motility in fresh ejaculate.

In this study, no correlation between the monitored elements was found. The monitored elements were $\mathrm{Zn}, \mathrm{Cu}, \mathrm{Mg}, \mathrm{Ca}$ and $\mathrm{P}$. This concurs with the work of Barrier-Battut et al. (2). In humans, a strong correlation between zinc concentration in seminal plasma and sperm motility exists $(24,25)$, but correlations with other elements has not been confirmed (26). From this view, a measurement of seminal plasma zinc concentration in fertile and subfertile stallions would be interesting.
Concentrations of $\mathrm{Na}, \mathrm{K}$ and $\mathrm{Cl}$ did not significantly differ between both observed groups. The role of these ions during sperm cooling and freezing, as well as the influence on sperm motility before and after storage is still not very clear. There are some studies about these ions in seminal plasma, but the results differ. Also, connection or correlation with semen quality or freezability is still not clear enough (1, 27-30).

The total protein was higher in the group of „poor" freezable ejaculates, but the difference was not statistically significant. It is known that protein concentration is lower in pre-spermatic fraction of ejaculate and the highest protein concentration is in the first phase of spermatic fraction in stallions (31). The total protein seems not to be a very important parameter in stallion ejaculate, but further research of single proteins in seminal plasma could give us some valuable information (1).

Also enzyme concentrations which were monitored in this study are not useful for ejaculate freezability predictions. It has been seen that gamaglutamyl-transferase (GMT) has an important role in sperm protection against oxidative stress, so it was expected that this enzyme could be a good marker for semen freezability $(32,33)$. Pesch et al. (29) and Kareskoski and Katila (1) found a correlation between GMT concentrations in seminal plasma and sperm motility. In our study, the concentration of this enzyme was higher in the group of ,good“ freezable ejaculates, but without statistical significance.

A very strong positive correlation between the concentration of lactate-dehydrogenase (LDH) and sperm motility was found (29), but in our study LDH concentrations were almost the same in both groups of ejaculates. Another difference between the ,good" and „poor" freezable group was in the concentration of alkaline phosphatase (ALP) but without statistical significance.

Concentrations of ALP were slightly higher in the group of "good“ freezable ejaculates. In stallions, as well as in dogs, ALP is an indicator of ejaculation $(34,35)$. In the study by Kareskoski et al. (30) there was a clear difference between ALP concentrations in seminal plasma in fertile and subfertile stallions. The same result was found in dogs, where there was also a correlation between the concentration of ALP and ejaculate freezability (36). Average values of other monitored enzymes: aspartate-amino-transferase (AST), creatine kinase (CK) and alanine amino-transferase (ALT) was the same in both groups or the difference was minimal.

Creatinine and urea are well known markers for the detection of urine in ejaculate. In both groups, levels of creatinine and urea were almost the same. In all of the samples, the border for urospermia was not exceeded. 
Effect of selected components of equine seminal plasma on semen freezability

Evaluation of the effect of seminal plasma components on sperm and the freezability of ejaculate is complicated. Only little information is available about some of the components, while concerning other components information is not complete, clear or uniform. So, in this part of the research there is still a lot of work and verification to be done.

\section{ACKNOWLEDGEMENT}

This project was supported by grant no. IGA 59/2013/ FVL.

\section{REFERENCES}

1. Kareskoski, M., Katila, T. (2008). Components of stallion seminal plasma and the effect of seminal plasma on sperm longevity. Anim Reprod Sci, 107, 249-256.

http://dx.doi.org/10.1016/j.anireprosci.2008.04.013 PMid:18556156

2. Barrier-Battut, I., Delajarraud, H., Legrand, E., Bruyas, J-F., Fieni, F., Tainturier, D., Thorin, C., Pouliquen, H. (2002). Calcium, magnesium, cooper, and zinc in seminal plasma of fertile stallions, and their relationship with semen freezability. Theriogenology 58, 229-232.

http://dx.doi.org/10.1016/S0093-691X(02)00744-6

3. Brinsko, S,P, Blanchard, T.L., Varner, D.D., Schumacher, J., Love, C.C., Hinrichs, K., Hartmen, D. (2011). Manual of equine reproduction. $3^{\text {rd }} \mathrm{ed}$. (pp. 19-192). Mosby, Missouri

4. Trein, C.R., Zikler, H., Bustamante-Filho, I.C., Malschitzky, E., Jobim, M.I.M., Sieme, H., Mattos, R.C. (2008). Equine seminal plasma proteins related with semen freezability. Anim Reprod Sci, 107, 252-253.

http://dx.doi.org/10.1016/j.anireprosci.2008.05.129

5. Jasko, D.L., Moran, D.L., Farlin, M.E., Squires, E.L. (1991). Effect of seminal plasma dilution or removal on spermatozoa motion characteristics of cooled semen. Theriogenology 35, 1059-1067. http://dx.doi.org/10.1016/0093-691X(91)90354-G

6. Braun, J., Sakai, M., Hochi, S., Oguri, N. (1994). Preservation of ejaculated and epididymal stallion spermatozoa by cooling and freezing. Theriogenology 41, 809-818. http://dx.doi.org/10.1016/0093-691X(94)90497-7

7. Alghamdi, A.S., Troedsson, M.H., Xue, J.L., Crabo, B.G. (2002). Effect of seminal plasma concentration and various extenders on post-thaw motility and glass wool - Sephadex filtration of cryopreserved stallion semen. Am J Vet Res 63, 880-885.

http://dx.doi.org/10.2460/ajvr.2002.63.880

PMid:12061536
8. Ben, W.X., Fu, M.T., Mao, L.K.,Ming, Z.W., Xiong, W.W. (1997). Effects of various concentration of native seminal plasma in cryoprotectant on viability on human sperm. Arch Androl 39, 211-216.

http://dx.doi.org/10.3109/01485019708987918

PMid:9352032

9. Aurich, J.E., Kuhne, A., Hoope, H., Aurich, C. (1996). Seminal plasma effects membrane integrity and motility of equine spermatoza after cryopreservation. Theriogenology 46, 791-797. http://dx.doi.org/10.1016/S0093-691X(96)00237-3

10. Katila, T., Anderson, M., Reilas, T., Koskinen, E. (2002). Post-thaw motility and viability of fractionated and frozen stallion ejaculates. Theriogenology 58, 241-244.

http://dx.doi.org/10.1016/S0093-691X(02)00783-5

11. Morrell, J.M., Pihl, J., Dalin, A.M., Johannisson, A. (2012). Restoration of seminal plasma to stallion spermatozoa selected by colloid centrifugation increase progressive motility but is determinal to chromatin integrity. Theriogenology 78, 345-352. http://dx.doi.org/10.1016/j.theriogenology.2012.02.009 PMid:22494676

12. Aurich, J.E., Kuhne, A., Hoope, H., Aurich, C. (1998). Effect of seminal plasma on stallion semen quality after cryopreservation. J Reprod Fertil Abstr Ser. 15: 34 .

13. Ackay, E., Reilas, T., Andersson, M., Katila, T. (2006). Effect of seminal plasma fractions on sperm survival after cooled storage. J Vet Med A, 53, 481-485. http://dx.doi.org/10.1111/j.1439-0442.2006.00882.x PMid:17054486

14. Taylor, K., Roberts, P., Sanders, K., Burton, P. (2009). Effect of antioxidant supplementation of cryopreservation medium on post-thaw integrity of human spermatozoa. RBM online 18: 184-189.

15. Pech-Sansores, A.G.C., Centurion-Castro, F.G., Rodriguez-Buenfil, J.C., Segura-Correa, J.C., Ake-Lopez, J.R. (2011). Effect of the addition of seminal plasma, vitamin $\mathrm{E}$ and incubation time on post-thawed sperm viability in boar semen. Tropical and Subtropical Agroecosystems 14, 965-971.

16. Therond, P., Auger, J., Legrand, A., Jouannet, P. (1996). $\alpha$-tocopherol in human spermatozoa and seminal plasma: relationship with mitility, antioxidant enzymes and leukocytes. Molecular Human Reproduction 10, 739-744.

http://dx.doi.org/10.1093/molehr/2.10.739

17. Mahmoud, G.B., Abdel-Raheem, S.M., Hussein, H.A. (2013). Effect of combination of vitamin $\mathrm{E}$ and selenium injections on reproductive performance and blood parameters of Ossimi rams. Small Ruminant Res 113, 103-108.

http://dx.doi.org/10.1016/j.smallrumres.2012.12.006 
18. Contri, A., De Amicis, I., Molinari, A., Faustini, M., Gramenzi, A., Robbe, D., Carluccio, A. (2011). Effect of dietary antioxidant supplementation on fresh semen quality in stallion. Theriogenology 75, 1319-1326. http://dx.doi.org/10.1016/j.theriogenology.2010.12.003 PMid:21295825

19. Deichsel, K., Palm, F., Koblischke, P., Budik, S., Aurich, C. (2008). Effect of a dietary antioxidant supplementation on semen quality in pony stallions. Theriogenology 69, 940-945.

http://dx.doi.org/10.1016/j.theriogenology.2008.01.007 PMid:18358523

20. Franco, J.S.V., Chaveiro, A., Góis, A., da Silva, F.M. (2013). Effects of $\alpha$-tocopherol and ascorbic acid on equine semen quality after cryopreservation. J Eq Vet Sci, 33, 787-793. http://dx.doi.org/10.1016/j.jevs.2012.12.012

21. Schmid-Lausigk, Y., Aurich, C. (2014). Influences of a diet supplemented with linseed oil and antioxidants on quality of equine semen after cooling and cryopreservation during winter. Theriogenology 81 , 966-973.

http://dx.doi.org/10.1016/j.theriogenology.2014.01.021 PMid:24576708

22. Blomfield, J., Tucker, L., McLeay, L., Morris, L.H.A. (2014). Evaluation of antioxidant dietary supplementation on semen quality parameters in New Zealand Standard bred stallions. J Eq Vet Sci, 34, 89. http://dx.doi.org/10.1016/j.jevs.2013.10.061

23. Bertelsmann, H., Keppler, S., Holtershinken, M., Bollwein, H., Behne, D., Alber, D., Bukalis, G., Kyriakopoulos, A., Sieme, H. (2010). Selenium in blood, semen, seminal plasma and spermatozoa of stallions and its relationship to sperm quality. Reprod Fertil Dev, 22, 886-891.

http://dx.doi.org/10.1071/RD10032 PMid:20450841

24. Fuse, H., Kazama, T., Ohta, S., Fujiuchi, Y. (1999). Relationship between zinc concentrations in seminal plasma and variuos sperm parameters. International Urology and Nephrology 31, 401-408. http://dx.doi.org/10.1023/A:1007190506587

25. Colagar, A.H., Marzony, E.T., Chaichi, M.J. (2009). Zinc levels in seminal plasma are associated with sperm quality in fertile and infertile men. Nutrition Research 29, 82-88. http://dx.doi.org/10.1016/j.nutres.2008.11.007

26. Wong, W.Y., Filk, G., Groenen, P.M., Swinkels, D.W., Thomas, C.M., Copius-Peereboom, J.H., Merkus, H.M., Steegers-Theunissen, R.P. (2001). The impact of calcium, magnesium, zinc, and cooper in blood and seminal plasma on semen parameters in men. Reprod Toxicol, 15, 131-136.

http://dx.doi.org/10.1016/S0890-6238(01)00113-7
27. Amann, R.P., Pickett, B.W. (1987). Principles of cryopreservation and a review of cryopreservation of stallion spermatozoa. J Eq Vet Sci, 7, 145-173.

http://dx.doi.org/10.1016/S0737-0806(87)80025-4

28. Kareskoski, M., Reilas, T., Andersson, M., Katila, T. (2006). Motility and plasma membrane integrity of spermatozoa in fractionated stallion ejaculates after storage. Reprod Dom Anim, 41, 33-38. http://dx.doi.org/10.1111/j.1439-0531.2006.00647.x PMid:16420325

29. Pesch, S., Bergmann, M., Bostedt, H. (2006). Determination of some enzymes and macro- and microelements in stallion seminal plasma and their correlations to semen quality. Theriogenology 66, 307-313.

http://dx.doi.org/10.1016/j.theriogenology.2005.11.015 PMid:16413936

30. Kareskoski, M., Reilas, T., Sankari, S., Andersson, M., Guvenc, K., Katila, T. (2010). Alkaline and acid phosphatase, $\beta$-glucuronidase and electrolyte levels in fractionated stallion ejaculates. Reprod Dom Anim, 45, 396-374.

http://dx.doi.org/10.1111/j.1439-0531.2009.01579.x PMid:20074319

31. Koskinen, E., Karlsson, M., Reilas, T., Sankari, S., Esala, A-L., Katila, T. (2002). Catalase activity and total protein in fractionated stallion seminal plasma. Theriogenology 58, 337-340.

http://dx.doi.org/10.1016/S0093-691X(02)00767-7

32. Kohdaira, T., Kinoshita, Y., Konno, M., Oshima, H. (1986). Distribution of G-glutamyl-transpeptidase in male reproductive system of rats and its age-related changes. Andrologia 18, 610-617.

http://dx.doi.org/10.1111/j.1439-0272.1986.tb01839.x PMid:2880528

33. Hinton, B.T., Lan, Z.J., Rudolph, D.B., Labus, J.C., Lye, R.J. (1998). Testicular regulation of epididymal gene expression. J Reprod Fertil, Suppl. 53, 47-58.

34. Kutzler, M.A., Solter, P.F., Hoffmann, W.E., Volkmann, D.H. (2003). Characterization and localization of alkaline phosphatase in canine seminal plasma and gonadal tissues. Theriogenology 60, 299-306. http://dx.doi.org/10.1016/S0093-691X(02)01366-3

35. Turner, R.M.O., McDonnell, S. (2003). Alkaline phosphatase in stallion semen: chracterization and clinical applications. Theriogenology 60, 1-10. http://dx.doi.org/10.1016/S0093-691X(02)00956-1

36. Kosiniak-Kamysz, K., Bittmar, A., Podstawski, Z. (2007). Alkalina phosphatase activity as a marker of dog semen freezability. Zootehniesi Biotehnologii 40, 131-135. 